Трач Юлія Василівна

ORCID ID 0000-0003-2963-0500

кандидат педагогічних наук,

Київський національний університет

культури і мистеитв

Київ, Украӥна

0411@ukr.net

\title{
ЗМІСТ ПОНЯТЬ «ВІЗУАЛЬНА ГРАМОТНІСТЬ» І «ВІЗУАЛЬНА КУЛЬТУРА»
}

Мета статті - виявлення змісту понять візуальних досліджень «візуальної культури» та «візуальної грамотності». У дослідженні використано метод інтерпретації, що дало змогу з'ясувати сутність досліджуваних об'єктів, в яких однаковою мірою присутні й духовні, і матеріальні, і художні форми предметності. Наукова новизна - розкрито сутність візуальної культури та візуальної грамотності як нових об'єктів соціогуманітарного знання. Результати та висновки - немає чітко означених і окреслених визначень щодо змісту понять «візуальна грамотність», «візуальна культура», «візуальна компетентність», «інформаційна компетентність», «медіаграмотність», «медіакультура», «медіакомпетентність».

Наведено процеси візуальної грамотності: вивчення психологічних процесів, що залучаються до процесу візуального 
сприйняття; використання технологій створення візуальних повідомлень; вивчення інтелектуальних методів, що дають змогу інтерпретувати, розуміти візуальну інформацію (за Ю. О. Аверкіним). Наведено базові елементи моделі візуальної компетентності (за Л. Г. Масімовою). Наголошено, що усвідомлення феномена візуальності може підвищувати керованість технічною візуальною культурою, яка вже стала невід'ємною частиною науки, суспільного життя, масового дозвілля, а також візуальною грамотністю, необхідність формування якої обумовлена соціальним замовленням суспільства, сформульованим у вигляді положення про необхідність розвитку інформаційної й комунікативної компетентностей. Визначили, що культурологічне дослідження даної проблематики передбачає звернення до історико-культурних аспектів питань побутування візуальної культури i формування візуальної грамотності, розгляд даних категорій як соціокультурних феноменів, а також всебічне вивчення історії й теорії медіа, візуальних мистецтв, візуального дизайну та інших сфер, пов’язаних з виробництвом і споживанням візуальних змістів.

Ключові слова: візуальна грамотність, візуальна культура, візуальні дослідження.

Трач Юлия Васильевна, кандидат педагогических наук, Киевский национальньй университет культуры и искусств, Киев, Украина 
Сущность понятий «визуальная грамотность» и «визуальная культура»: культурологический аспект

Цель статьи - выявление содержания понятий визуальных исследований - «визуальной культуры» и «визуальной грамотности». В исследовании использован метод интерпретации, что позволило выяснить сущность исследуемых объектов, в которых в равной степени присутствуют и духовные, и материальные, и художественные формы предметности. Научная новизна - раскрыта сущность визуальной культуры и визуальной грамотности как новых объектов социогуманитарного знания. Результаты и выводы - отмечена размытость содержания понятий «визуальная грамотность», «визуальная культура», «визуальная компетентность», «информационная компетентность», «медиаграмотность», «медиакультура», «медиакомпетентность».

Приведены процессы визуальной грамотности: изучение психологических процессов, вовлекающиеся в процесс визуального восприятия; использование технологий создания визуальных сообщений; изучение интеллектуальных методов, позволяющих интерпретировать, понимать визуальную информацию (по Ю. А. Аверкиным). Приведены базовые элементы модели визуальной компетентности (по Л. Г. Масимовой). Отмечено, что осознание феномена визуальности может повышать управляемость технической визуальной культурой, которая уже стала неотъемлемой частью науки, общественной жизни, массового досуга, а также визуальной грамотностью, необходимость формирования которого обусловлена социальным заказом 
общества, сформулированным в виде положения о необходимости развития информационной и коммуникативной компетентности. Отмечено, что культурологическое исследование данной проблематики предполагает обращение к историко-культурных аспектам вопросов бытования визуальной культуры и формирования визуальной грамотности, рассмотрение данных категорий как социокультурных феноменов, а также всестороннее изучение истории и теории медиа, визуальных искусств, визуального дизайна и других сфер, связанных с производством и потреблением визуальных смыслов.

Ключевые слова: визуальная грамотность, визуальная культура, визуальные исследования.

Trach Yulia, PhD of Pedagogical Sciences, Kyiv National University of Culture and Arts, Kyiv, Ukraine

The essence of the concepts of «visual literacy» and «visual culture»: cultural aspects

The purpose of the article - identify the nature of some of visual studies - «visual culture» and «visual literacy». The study used the method of interpretation, which helped to clarify the nature of the objects, which are present equally spiritual and physical, and artistic forms of objectivity. Scientific novelty - the essence of visual culture and visual literacy as new facilities socio-humanitarian knowledge. Results and conclusions - emphasized the content blur the concepts of «visual literacy», «visual culture», «Visual competence», «information competence», «medialiteracy», «mediaculture», «mediacompetence». 
An processes visual literacy: the study of the psychological processes that are involved in the process of visual perception; using technologies of visual communications; study of intelligent methods that allow you to interpret and understand visual information (by Y. O. Averkin). An basic elements of visual model of competence (by L. G. Masimov). Emphasized that understanding the phenomenon of visuality can improve handling technical visual culture, which has become an integral part of science, social life, mass entertainment and visual literacy, which is due to the necessity of forming social order of society formulated in the form of provision of information and the need communicative competence. It is noted that cultural studies of this problem involves an appeal to the historical and cultural aspects of matters of existence of visual culture and the formation of visual literacy, consideration of such categories as social and cultural phenomena and comprehensive study of the history and theory of media, visual arts, visual design and other areas, floor ' related to the production and consumption of visual contents.

Key words: visual literacy, visual culture, visual studies.

Вступ. Ускладнення форм і каналів комунікації, зростання культурного розмаїття та глобалізаційні процеси в сучасному суспільстві підвищують вимоги до грамотності- комплексного феномена, який сприяє критичному осмисленню дійсності людьми. Грамотність як один із чинників соціального і культурного розвитку суспільства важлива для особистісного розвитку людини в їі здатності розуміти й використовувати різні типи інформації в 
різних сферах життєдіяльності. Загальне поняття грамотності $\epsilon$ досить складним і постійно уточнюється відповідно до викликів сучасності й розширення своїх видів- культурна грамотність, інформаційна грамотність, медіаграмотність, кроскультурна грамотність, екологічна грамотність, трансграмотність та ін. [8]. У цьому переліку останнім часом з’явилася й візуальна грамотність, яка має на меті уміння планувати й здійснювати діяльність, пов'язану 3 візуалізацією інформації на основі самоаналізу, самоконтролю й самооцінки.

Виявлення сутності одних 3 основоположних понять візуальних досліджень - «візуальної культури» та «візуальної грамотності» і $є$ метою даної статті. Актуальність даного дослідження обумовлена тим, що в епоху нинішнього візуального буму проблеми візуальності викликають величезний інтерес вчених різних галузей гуманітарної науки. Проблематика візуального вивчається вже давно - найбільше уваги приділялося саме вивченню технічної візуальної культури, яка охарактеризувала XIX ст. появою фотокамери i кінокамери й продовжила свій бурхливий розвиток у XX-XXI ст. Однак, нині вимагають перегляду явища, проаналізовані та пояснені гуманітарною наукою середини XX ст., але які продовжують розвиватися і по цей день. Попри широке дослідження проблематики візуального представниками різних галузей знання, сьогодні дуже мало спеціальних праць, присвячених термінології, методології аналізу тощо візуальної культури, i, зокрема, візуальної грамотності. Можна лише відзначити праці Р. Арнхейма («Искусство и 
визуальное восприятие»), Ж. Елліса («Визуальная беллетристика: кино, телевидение, видео»), А. Каїро («Функціональне мистецтво: вступ до іконографіки та візуалізації»), Л. Г. Масімової («Візуальна грамотність в системі медіаосвіти»), К. Е. Разлогова («Искусство экрана: от синематографа до Интернета»), В. М. Розіна («Визуальная культура и восприятие. Как человек видит и понимает мир»), Є.В. Сальнікової («Феномен визуального: от древних истоков к началу XXI века»), Н. I. Череповської («Формування візуальної медіакультури особистості засобами медіаосвіти»), С. П. Шумаєвої («Розвиток мас-медійних навчальних технологій в середніх закладах освіти США»), в яких тією чи іншою мірою розкрито, уточнено зміст досліджуваних понять, хоча й в певному контексті, що істотно звужує розуміння їх змісту. Зокрема, в центрі уваги деяких дослідників опиняються естетичні особливості фотографії, кіно, телебачення, аналіз специфіки їх художніх прийомів у порівнянні 3 традиційними мистецтвами, насамперед, літератури, театру, живопису. Інші ж, навпаки, зосереджуються не лише на художніх аспектах досліджуваного предмета, а й на ролі окремих елементів візуальної технічної культури в соціальному просторі, в житті індивіда тощо.

3'ясування змісту даних понять має важливе значення для теоретичної та практичної діяльності. Висловлене в стислому вигляді знання про візуальну культуру, i, зокрема, візуальну грамотність, стане істотним моментом в пізнанні дійсності, а також дасть можливість відрізнити їх від інших понять, застереже від змішування з дотичними категоріями, від плутанини в міркуваннях. 
Слова «візуальне» і «візуальність» (що походять від латинського «visualis» - «зоровий, візуальний», від visus «зір» i videre «бачити») увійшли в професійний обіг порівняно недавно, в останнє десятиліття XX ст., і використовувалися в порівняно вузькому значенні, наприклад, аудіо-візуальні технології. Сьогодні візуальними прийнято називати ті елементи культури, які хоча б деякою мірою пов'язані 3 технічною культурою фотографії, кінематографу, відео, Інтернету.

Наслідком великого інтересу до даної теми стала поява нових досліджень, які по-новому інтерпретують проблему зображення. Однією 3 таких міждисциплінарних галузей $\epsilon$ візуальні дослідження, для оформлення яких важливим вважається поява в другій половині ХХ ст. нових форм мистецтва й невизначене розмежування меж між мистецтвом і не мистецтвом. У системі координат традиційного мистецтвознавства й класичної естетики не виявилося апарату аналізу нових форм мистецтва - «нова речевість» сучасного мистецтва (цифрового мистецтва, media-арту, біоарту) зажадала нової мови опису [7]. Саме в межах візуальних досліджень вченими вивчаються питання візуальної грамотності як здатності аналізувати, створювати i використовувати візуальну реальність 3 метою розвитку критичного мислення, навичок ефективної комунікації і конструктивного прийняття рішень [13], i візуальної культури як частини поняття «культура», що розвиває здібності сприйняття візуальних образів, вміння їх аналізувати, інтерпретувати, оцінювати, зіставляти, подавати і створювати на цій основі індивідуальні художні образи [3]. 
До безпосередніх «попередників» візуальних досліджень належать культуральні дослідження (cultural studies), культурну історію (cultural history), соціальну історію і соціологію мистецтва, загальну іконологію (Е. Панофски, А. Варбург, Д. Т. Мітчелл), а також психологію зорового сприйняття (Т. Ліппс, В. Вундт, P. Архейм). Д. Т. Мітчелл називає цю ситуацію симптомом упущення фундаментальних дисциплін: у візуальних дослідженнях розгортаються ті проблеми, які були маргінальними в класичному мистецтвознавстві та естетиці, які оперували категорією стилю і сформованими навколо ідеї мимезису [7].

Виникнення візуальної культури як предметної галузі дослідження стало результатом тривалих i складних методологічних пошуків й емпіричних досліджень. Для деяких критиків візуальна культура залишається просто «історією образів», що містить семіотичні поняття репрезентації (Н. Брізон, М. Холлі, К. Моксі) [10]. Для інших теоретиків появу проблемної сфери візуальної культури ознаменувало виникнення соціології візуального: «соціальної теорії видимості» (С. Дженкс) і «візуальної соціології» (П. Штомпка), де фотографія стає методом дослідження. Однак найбільш значущими і впливовими в цьому напрямі є дослідження таких авторів як М. Баксандалл, Н. Брайсон, Т. Дж. Кларк, Г. Поллок та ін., чиї праці не лише окреслюють нову проблемну галузь, а й виокремлюють важливі методологічні й дисциплінарні питання.

Візуальна культура, на думку антропологів, складається 3 чотирьох елементів: 1) поняття (містяться у мові, завдяки їм стає 
можливим впорядкувати досвіду людей - форма, колір, смак предметів); 2) відносини (візуальна культура не лише виокремлює ті чи інші частини світу з допомогою понять, але також виявляє, як ці складові частини пов'язані між собою - у просторі i часі, за значенням, на основі причинної обумовленості); 3) цінності (загальноприйняті переконання щодо цілей, до яких людина повинна прагнути, вони становлять основу моральних принципів); 4) правила (ці елементи регулюють поводження людей відповідно до цінностей візуальної культури; цінності не лише самі мають потребу в обгрунтуванні, а й можуть слугувати обгрунтуванням) $[12$, c. 62$]$.

Отже, візуальна культура - новий міждисциплінарний напрям, що виник на перетині філософії, теорії культури, соціології та мистецтвознавства, центральною проблемою якого є дослідження культурної логіки «постмодерністського», «мас-медійного», «візуального» повороту [3]. Візуальна культура сьогодні стає домінуючою формою «культури як такої».

Як зазначає один 3 визнаних теоретиків у даній сфері професор Нью-Йоркського університету Н. Мірзоєв, візуальна культура постає як середовище життя сучасної людини, яка змушена жити в полі візуальних образів, споживаючи й виробляючи їх в результаті особливостей професійного та повсякденного життя техногенного суспільства. Серед характеристик «візуального» стилю життя дослідник виокремлює: глобалізацію, високу швидкість виробництва i споживання візуальних продуктів, екранів, домінування візуальних медіа в усіх 
сферах повсякденного життя, ослаблення здібностей критичного мислення [11].

Як невід’ємна частина загальної культури особистості, візуальна грамотність - це компонент у складі інформаційної та комунікативної ключових компетентностей. Це сукупність знань, умінь й особистісних якостей індивідуума, необхідних для активної, самостійної діяльності, пов'язаної з процесом сприйняття, перетворення і передання інформації. Візуальну грамотність можна уявити як: а) знання графічних методів, правил i засобів відображення і читання інформації, іiі збереження, передання, перетворення, використання в діяльності; б) вміння застосувати графічні знання в інформаційно-комунікативній діяльності; в) розуміння значущості візуалізації інформації в різних видах діяльності; г) усвідомлення власної діяльності, пов'язаної 3 візуалізацією інформації; д) вирішення творчих завдань 3 елементами проектної діяльності, створення власних ідеальних і реальних моделей об'єктів, процесів, явищ; е) реалізація задуму, зокрема, з використанням різноманітних засобів і мультимедійних технологій [6].

«Візуальна грамотність - це здатність сприймати, аналізувати, оцінювати, брати участь у комунікативному процесі 3 допомогою будь-якого зображення» [1, с. 16]. Дане визначення дає змогу включити, але не обмежувати, будь-які комбінації синтезу засобів візуальної комунікації, як, наприклад, фотографія і малюнок, виставкова експозиція і схеми, архітектура та ін. При цьому, 
візуальна грамотність, як галузь освіти, яка має справу з тим, що ми бачимо і як це інтерпретуємо, в своїй основі має три процеси:

1) вивчення психологічних процесів, що залучаються до процесу візуального сприйняття;

2) використання технологій створення візуальних повідомлень;

3) вивчення інтелектуальних методів, що дають змогу інтерпретувати, розуміти візуальну інформацію [1, с. 16].

Розгляд візуальної грамотності як «розуміння природи візуального повідомлення, знання законів його сприйняття і пізнання, володіння технікою створення й артикуляції візуального образу» [9] дає підстави Л. Г. Масімовій запропонувати в роліі базових елементів моделі візуальної компетентності:

1) вміння перевести візуальні образи в вербальну мову;

2) вміння створити на основі зображення вербальний текст;

3) розуміння символічної природи візуального образу;

4) знання загальнолюдських i національних візуальних стереотипних образів-символів;

5) обізнаність 3 візуальними жанрами сучасного медіаконтенту;

6) трактування смислового навантаження композиції;

7) розроблення комунікативних ідей;

8) створення власної візуальної інформації;

9) уміння мотивувати доцільність форми подання інформації [9]. 
Зокрема Є. М. Полюдова звертає увагу, що поняття візуальної грамотності пов'язане 3 такими компетентнісними характеристиками, як:

- розвиток високої швидкості виробництва і споживання візуальних продуктів;

- формування структурної екранності сприйняття i виробництва образів;

- розвиток усвідомлення домінування візуальних медіа в усіх сферах повсякденного життя;

- практичне освоєння сучасного навколишнього світу як через створення вивірених продуктів у сфері технологій;

- формування критичного мислення в процесі відбору матеріалу [11].

Поряд 3 термінами «візуальна грамотність» і «візуальна культура» можна зустріти й поняття «візуальна компетентність», «інформаційна компетентність», «медіаграмотність», «медіакультура», «медіакомпетентність» та ін. Їхня актуальність і термінологічний аналіз вимагають окремого глибокого дослідження, в межах даної статті варто звернути увагу лише на деякі моменти невідповідності в їхньому трактуванні. Так, С. С. Зорін і Л. К. Веретенникова пишуть, що «візуальна культура багаторівнева система культури зорового сприйняття, переробки $\mathrm{i}$ відображення візуальної інформації» [5, с. 3], що, насправді, збігається зі змістом поняття «візуальна грамотність».

Наостанок варто зазначити, що візуальні дослідження тісно пов'язані з культурологією, насамперед, в розумінні об'єкта 
вивчення як цілісності, в якій однаковою мірою присутні і духовні, i матеріальні, i художні форми предметності, в розумінні тотальності свого предмета вивчення, а також можливості 3 його допомогою вибудовувати типологічні характеристики історичних епох або цивілізацій, поєднання візуального поля, розширення його «природного», «звичного» стану» [2, с. 243].

Усвідомлення феномена візуальності може підвищувати керованість технічною візуальною культурою, яка вже стала невід'ємною частиною науки, суспільного життя, масового дозвілля, а також візуальною грамотністю, необхідність формування якої обумовлена соціальним замовленням суспільства, сформульованим у вигляді положення про необхідність розвитку інформаційної і комунікативної компетентностей. Розуміння внутрішньої логіки розвитку візуальної культури сприятиме прогнозуванню тих чи інших ऑiі тенденцій, активізації в ній творчого, позитивного потенціалу.

Отже, новизна даної статті полягає в актуалізації необхідності чіткого окреслення меж терміна «візуальність», а також структурування візуальної культури, що повинно враховуватися при подальшому вивченні соціокультурних процесів. Це дасть змогу уточнити специфічні властивості таких культурних явищ, суміжних 3 візуальними, як видовищна культура, образотворче мистецтво, невізуальні технології мас-медіа.

Культурологічне дослідження даної проблематики передбачає звернення до історико-культурних аспектів питань побутування візуальної культури і формування візуальної грамотності, розгляд 
даних категорій як соціокультурних феноменів, а також всебічне вивчення історії та теорії медіа, візуальних мистецтв, візуального дизайну та інших сфер, пов'язаних з виробництвом і споживанням візуальних змістів.

\section{Список використаних джерел}

1. Аверкин Ю. А. Развитие визуальной грамотности студентов-дизайнеров на занятиях по фотографике : дис ... канд. педагог. наук : 13.00.02 / Аверкин Юрий Александрович ; Моск. гос. гуманитар. ун-т им. М. А. Шолохова. - Москва, 2010. - 220 с.

2. Баль М. Визуальный эссенциализм и объект визуальных исследований / М. Баль // Логос. - 2012. - № 1. - С. 212-249.

3. Дубовая Н. В. Визуальная культура в аспекте современности [Электронный ресурс] / Н. В. Дубовая. - Режим доступа : https://sibac.info/conf/pedagog/iii/35579. - Загл. с экрана.

4. Вдовина Т. В. Визуальные исследования: основные методологические подходы [Электронный ресурс] / Т. В. Вдовина. Режим доступа : http://cyberleninka.ru/article/n/vizualnye-issledovaniya-osnovnyemetodologicheskie-podhody. - Загл. с экрана.

5. Зорин С. С. Формирование визуальной культуры / С. С. Зорин, Л. К. Веретенникова. - Глазов, 2002. - 188 с.

6. Кальницкая Н. И. Развитие визуальной грамотности старшеклассников в процессе обучения : дис ... канд. педагог. наук : 13.00.01 / Наталья Ивановна, Омский гос. техн. ун-т. - Омск, 2006. - 161 c. 
7. Крышталева М. К. Визуальные исследования: генеалогия и культурологический потенциал [Электронный ресурс] / M. К. Крышталева.

Режим доступа : http://cyberleninka.ru/article/n/vizualnye-issledovaniya-genealogiya-ikulturologicheskiy-potentsial. - Загл. с экрана.

8. Мальковская И. А. Визуальная культура: проблема самоидентичности [Электронный ресурс] / М. И. Александровна. Режим доступа : http://cyberleninka.ru/article/n/vizualnaya-kulturaproblema-samoidentichnosti. - Загл. с экрана.

9. Масімова Л. Г. Візуальна грамотність в системі медіаосвіти [Электронный ресурс] / Л. Г. Масімова. - Режим доступу : http://snphilolsocom.crimea.edu/arhiv/2013/uch_26_3filol/029_masi.pdf. Назва $з$ екрану.

10.Павлова О. Ю. Візуальна культура як поле ліквідності модерну [Электронный ресурс] / О. Ю. Павлова. - Режим доступу : www.irbis-nbuv.gov.ua/.../cgiirbis_64.exe?...10....- Назва з екрану.

11.Полюдова Е.Н. Визуальная культура и современное художественное образование [Электронный ресурс] / Е. Н. Полюдова. - Режим доступа : education.ru/electronic-journal/vizualnaya-kultura-i-sovremennoehudozhestvennoe-obrazovanie. - Загл. с экрана.

12.Розин В. М. Визуальная культура и восприятие: как человек видит и понимает мир / В.М.Розин. - Москва : ЛИБРОКОМ, 2009. - 272 с.

13.Федоренко С. Грамотність як комплексний педагогічний феномен у вищій освіті США [Електронний ресурс] / 
С. Федоренко. - Режим доступу: nbuv.gov.ua/cgi.../cgiirbis_64.exe?.... - Назва з екрану.

\section{References}

1. Averkin, Yu. (2010). The development of visual literacy of design students during lectures on photography, D.Ed. Moscow State Humanitarian University named after M. A Sholokhov.

2. Bal, M. (2012). Visual essentialism and the suject of visual research. Logos. [Logos], no. 1, pp. 212-249.

3. Dubovaya, N. (2017). Visual culture in the aspect of modernity. Available at: <https://sibac.info/conf/pedagog/iii/35579> [Accessed 10 May 2017].

4. Vdovina, T. (2017). Visual Research: Basic Methodological Approaches. Available at: <http://cyberleninka.ru/article/n/vizualnyeissledovaniya-osnovnye-metodologicheskie-podhody> [Accessed 10 May 2017].

5. Zorin, S. (2002). The formation of visual culture. Glazov.

6. Kalnitskaya, N. (2006). The development of visual literacy of high school students in the process of teaching. D.Ed. Omsk State Technical University.

7. Kryshtaleva, M. (2014). Visual research: genealogy and culturological potential. Available at: <http://cyberleninka.ru/article/n/vizualnye-issledovaniya-genealogiya-ikulturologicheskiy-potentsial> [Accessed 10 May 2017]. 
8. Malkovskaya, I.A. (2008). Visual culture: the problem of selfidentity. Available at: <http://cyberleninka.ru/article/n/vizualnayakultura-problema-samoidentichnosti> [Accessed 10 May 2017].

9. Masimova, L. (2015). Visual Literacy in the system of media education. Available at: <http://snphilolsocom.crimea.edu/arhiv/2013/uch_26_3filol/029_masi.p df $>$ [Accessed 10 May 2017].

10. Pavlova, O. (2015). Visual culture as a field of liquidity of Art Noveau. Available at: <www.irbis-nbuv.gov.ua/.../ cgiirbis_64.exe? ... 10 .... > [Accessed 10 May 2017].

11. Polyudova, E. (2012) Visual culture and contemporary art education. Available at: <http://www.art-education.ru/electronicjournal/vizualnaya-kultura-i-sovremennoe-hudozhestvennoeobrazovanie> [Accessed 10 May 2017].

12. Rozin, V. (2009). Visual culture and perception: how a person sees and understands the world. Moscow: LIBROKOM.

13. Fedorenko, S. (2014). Literacy as a complex phenomenon in higher education in the US. Available at: <www.irbis-nbuv.gov.ua/cgi ... / cgiirbis_64.exe? ....> [Accessed 10 May 2017].

(C) Трач Ю. В., 2017 